\title{
One-Step Synthesis of Pd-M/ZnO (M=Ag, Cu, and Ni) Catalysts by $\gamma$-Irradiation and Their Use in Hydrogenation and Suzuki Reaction
}

\author{
Mi-Ran Kim and Seong-Ho Choi \\ Department of Chemistry, BK 21 NanoBiosensor Research Team, Hannam University, Daejeon 305-811, South Korea \\ Correspondence should be addressed to Seong-Ho Choi, shchoi@hnu.kr
}

Received 2 October 2008; Revised 23 December 2008; Accepted 27 January 2009

Recommended by Sherine Obare

$\mathrm{ZnO}$-supported $\mathrm{Pd}, \mathrm{Pd}-\mathrm{Ag}, \mathrm{Pd}-\mathrm{Cu}$, and $\mathrm{Pd}-\mathrm{Ni}$ catalysts $(\mathrm{Pd}-\mathrm{M} / \mathrm{ZnO})$ were prepared in $\mathrm{MeOH} / \mathrm{H}_{2} \mathrm{O}$ mixture $(4 / 1$, v/v-\%) by $\gamma$ irradiation at room temperature. Small mono- and bimetallic nanoparticles were loaded on the surface of $\mathrm{ZnO}$ nanopowder as confirmed with TEM, TEM-EDXS, XRD, and ICP-AES data. The catalytic efficiency against Pd-M/ZnO was determined in hydrogenation and Suzuki reaction and compared with the commercial Pd/C catalyst. The Pd-Ag/ZnO showed the highest catalytic efficiency in the Suzuki reaction.

Copyright (๑) 2009 M.-R. Kim and S.-H. Choi. This is an open access article distributed under the Creative Commons Attribution License, which permits unrestricted use, distribution, and reproduction in any medium, provided the original work is properly cited.

\section{Introduction}

Palladium catalysts are used in cross-coupling reaction (e.g., Suzuki, Heck reaction, Sonogashira, etc.). While homogeneous palladium catalysts are not used in industrial application because of the difficulty in separating and recycling for the catalysts. Many heterogeneous palladium catalysts have been made for recycling mainly by immobilizing palladium onto inorganic supports or polymers [1-5]. Palladium nanoparticles, colloidal palladium species, and polymerincarcerated palladiums have been also reported as recycling catalysts $[6,7]$. However, they often suffer from problems such as low catalytic efficiency, degradation, the leaching of the metal species, and a difficult synthetic procedure.

Palladium catalyzed Heck or Suzuki C-C forming reactions using aryl bromides as one of the substrates are among the most versatile reactions for organic synthesis, since they are compatible with a large variety of functional groups. Many palladium complexes have been investigated as homogeneous catalysts and many supported palladium complexes as heterogeneous catalysts for these reactions. An extensive range of reaction conditions have been explored and literature on this subject has very recently been reviewed [8]. In a previous paper [9], carbon-supported monometallic $\mathrm{Pd}$ and bimetallic $\mathrm{Pd}-\mathrm{M}(\mathrm{M}=\mathrm{Ag}, \mathrm{Ni}$, and $\mathrm{Cu})$ nanoparticles were synthesized by $\gamma$-irradiation at room temperature without reducing agents. The prepared $\mathrm{Pd} / \mathrm{C}$ and $\mathrm{Pd}-\mathrm{M} / \mathrm{C}$ catalysts were applied as catalyst in $\mathrm{C}-\mathrm{C}$ coupling reaction (specially, Suzuki and Heck reactions) in EtOH and in acetonitrile, respectively. The $\mathrm{Pd}-\mathrm{Cu} / \mathrm{C}$ catalysts showed high catalytic efficiency in the Suzuki- and Heck-type reactions. However, the metallic nanoparticle based on Pd is mainly aggregated on carbon surface because carbon supporters have hydrophobic properties, while the metallic particles have hydrophilic properties. In order to increase dispersion of metallic nanoparticles, we selected hydrophilic property supporters.

On the other hand, the aromatic amines are of significant industrial importance because they are widely used as the intermediates for synthesis of dyes, pharmaceuticals, and agrochemicals [10]. Aromatic amines are generally prepared by the reduction of aromatic nitro compounds. Two general methods are used for the reduction of aromatic nitro compounds in industry: catalytic hydrogenation [11, 12] and stoichiometric reduction reaction [13-17]. The catalytic hydrogenation is a clean and convenient method for producing amine in high yield. However, little has been reported about synthesis of aromatic amine from aromatic nitro compound by using monometallic or bimetallic nanoparticles prepared by $\gamma$-irradiation, to our knowledge. 


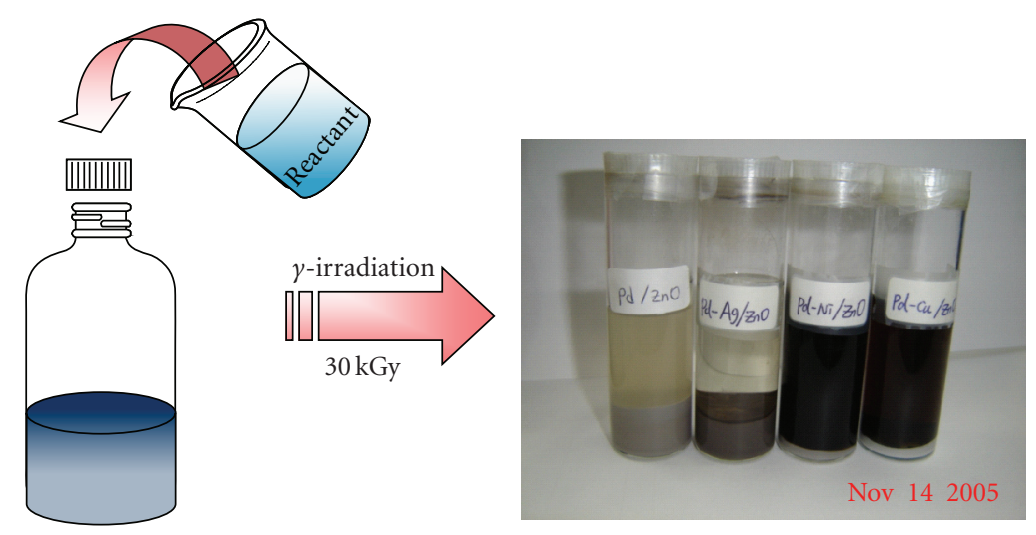

Scheme 1: Preparation procedure of $\mathrm{Pd}-\mathrm{M}(\mathrm{M}=\mathrm{Cu}, \mathrm{Ni}$ and $\mathrm{Ag}) / \mathrm{ZnO}$ catalyst in $\mathrm{MeOH}$-water mixture by using $\gamma$-irradiation. Reactants: $\mathrm{CH}_{3} \mathrm{OH}(200 \mathrm{~mL})$ and water $(50 \mathrm{~mL})$ as solvent, PVP as a stabilizer, palladium nitrate, silver nitrate, copper nitrate, and nickel nitrate, ZnO powder (10.0 g).

Herein, we described a simple method for preparing $\mathrm{ZnO}$-supported $\mathrm{Pd}(\mathrm{Pd} / \mathrm{ZnO})$ and $\mathrm{Pd}-\mathrm{M}(\mathrm{M}=\mathrm{Cu}, \mathrm{Ni}$, and $\mathrm{Ag})$ nanoparticles $(\mathrm{Pd}-\mathrm{M} / \mathrm{ZnO})$ by $\gamma$-irradiation at room temperature without any reduction agents. The prepared $\mathrm{Pd} / \mathrm{ZnO}$ and $\mathrm{Pd}-\mathrm{M} / \mathrm{ZnO}$ catalysts were characterized by TEM, TEM-EDXS, and ICP-AES spectroscopy. Furthermore, the catalytic efficiencies of the $\mathrm{Pd} / \mathrm{ZnO}$ and $\mathrm{Pd}-\mathrm{M} / \mathrm{ZnO}$ catalysts were evaluated in hydrogenation and Suzuki reactions.

\section{Experimental}

2.1. Chemicals. $\mathrm{PdNO}_{3}, \mathrm{CuNO}_{3}, \mathrm{NiNO}_{3}$, Iodobenzene, 2iodothiophene, 4-iodobenzoic acid, phenyl boronic acid, and 4-nitrophenol were analytical reagent grade and supplied by Sigma-Aldrich Korea (Seoul, Korea). $\mathrm{AgNO}_{3}$ was purchased from Kojima Chemicals Co., Ltd. (Japan). The $\mathrm{ZnO}$ nanopowder was obtained from Sunjin Chemical Co., Ltd. (Korea). The Poly (vinylpyrrolidone), PVP (molecular weight of 40000 ), was purchased from Junsei Co. Ltd. (Japan). All the other chemicals were of reagent grade and used without further purification.

2.2. Radiolytic Synthesis of $P d-M / Z n O(M=A g, N i$, and $C u)$ Catalysts. Scheme 1 shows the preparation procedure of Pd$\mathrm{M} / \mathrm{ZnO}$ catalysts by using $\gamma$-irradiation. The $\mathrm{Pd}-\mathrm{Ag} / \mathrm{ZnO}$ catalyst was prepared by the following procedure. First, $\mathrm{Pd}\left(\mathrm{NO}_{3}\right)_{2}, \mathrm{AgNO}_{3}, \mathrm{PVP}$ as anchor agents, and $\mathrm{ZnO}$ nanopowder $(10.0 \mathrm{~g})$ as supporting material were dispersed in a mixed solution of $\mathrm{MeOH}$-water $(4 / 1, \mathrm{v} / \mathrm{v}-\%)$. Next, nitrogen gas was bubbled through the solution for 30 minutes to remove the oxygen. The dispersed solution was then irradiated by the $\gamma$-ray from a Co-60 source under atmospheric pressure and ambient temperature. The total irradiation dose was $30 \mathrm{kGy}$ (a dose rate $=1.0 \times 10^{4} \mathrm{~Gy} /$ hour). The $\mathrm{Pd} / \mathrm{ZnO}, \mathrm{Pd}-\mathrm{Ni} / \mathrm{ZnO}$, and $\mathrm{Pd}-\mathrm{Cu} / \mathrm{ZnO}$ catalysts were also prepared by a similar method. After $\gamma$-irradiation, the reaction mixture was centrifuged at $1600 \mathrm{rpm}$ for separation of the $\mathrm{Pd}-\mathrm{M} / \mathrm{ZnO}$ catalysts, which were then dried at $50^{\circ} \mathrm{C}$ in a vacuum oven for 6 hours.
TABle 1: ICP data of Pd-M (M=Ag, Cu, Ni)/ZnO catalysts prepared by $\gamma$-irradiation.

\begin{tabular}{lcccc}
\hline & $\mathrm{Pd}(\%)$ & $\mathrm{Ag}(\%)$ & $\mathrm{Cu}(\%)$ & $\mathrm{Ni}(\%)$ \\
\hline $\mathrm{Pd} / \mathrm{ZnO}$ & 19.4 & & & \\
$\mathrm{Pd}-\mathrm{Ag} / \mathrm{ZnO}$ & 9.73 & 8.53 & & \\
$\mathrm{Pd}-\mathrm{Cu} / \mathrm{ZnO}$ & 6.36 & & 11.3 & \\
$\mathrm{Pd}-\mathrm{Ni} / \mathrm{ZnO}$ & 5.06 & & & 0.650 \\
\hline
\end{tabular}

\subsection{Catalytic Test}

2.3.1. Hydrogenation. For studying the catalytic efficiency for $\mathrm{Pd}$ and $\mathrm{Pd}-\mathrm{M} / \mathrm{ZnO}$ catalysts, the reaction mixtures were prepared with $\mathrm{NaBH}_{4}(0.1 \mathrm{M})$ as hydrogen source and aromatic nitro compounds $(0.01 \mathrm{M})$. Pd-M/ZnO catalysts $(5 \mathrm{mg})$ were added in the prepared reaction mixture. The UV-visible spectra during reduction of aromatic nitro compounds using $\mathrm{Pd}-\mathrm{M} / \mathrm{ZnO}$ catalysts were recorded continuously. In order to compare the reduction of aromatic nitro compound, the standard aromatic amine compounds were also measured by UV-visible spectra.

2.3.2. Suzuki Reaction. In a $100 \mathrm{~mL}$ three-necked flask, an aryl halide $(3.0 \mathrm{mmol})$, phenyl boronic acid $(6.0 \mathrm{mmol})$, $\mathrm{Pd}-\mathrm{M} / \mathrm{ZnO}$ catalyst $(43.0 \mathrm{mg}$, ca. $4.0 \mathrm{mmol})$, and $\mathrm{K}_{3} \mathrm{PO}_{4}$ $(12.0 \mathrm{mmol})$ were added in $50 \mathrm{~mL} \mathrm{EtOH}$. Three different types of aryl halides were tested. The mixture solution was reacted at $78^{\circ} \mathrm{C}$ for 3 hours under nitrogen atmosphere. In order to remove the $\mathrm{Pd}-\mathrm{M} / \mathrm{ZnO}$ catalyst, the reaction solution was filtered through a Whatman filter paper (no.2). The filtered solution was filtered again through $0.45 \mu \mathrm{m}$ membrane filter (MFS-25 PVDF). Finally the solvent was evaporated. The yield was determined by HPLC with a ODS column.

2.4. Characterization. UV-visible spectra were measured by using a Shimadzu UV-160 digital spectrophotometer (Kyoto, Japan) in a $1 \mathrm{~cm}$ quartz cuvette. Field emission transmission electron microscopy (FE-TEM) images were collected at 


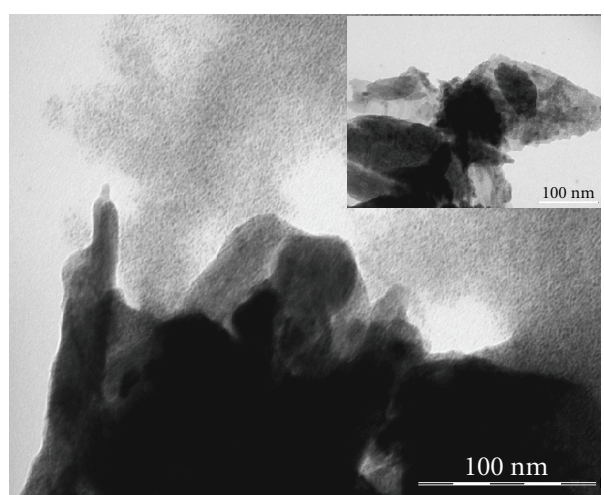

(a)

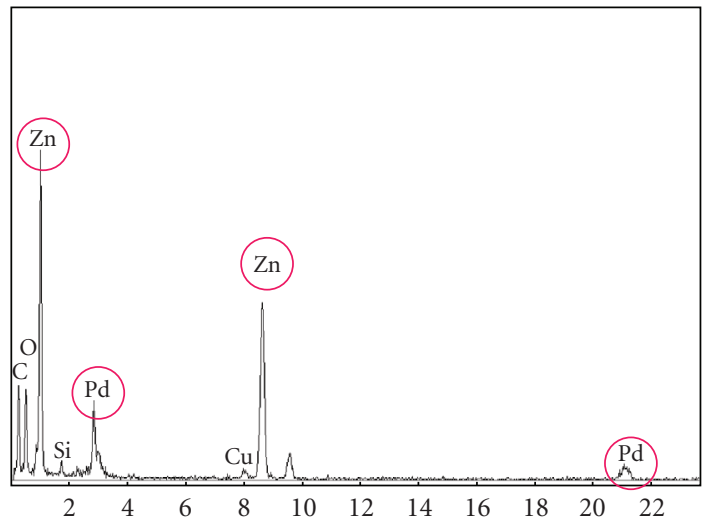

(b)

Figure 1: TEM images (a) and EDXS data (b) of the Pd/ZnO catalyst prepared by $\gamma$-irradiation.

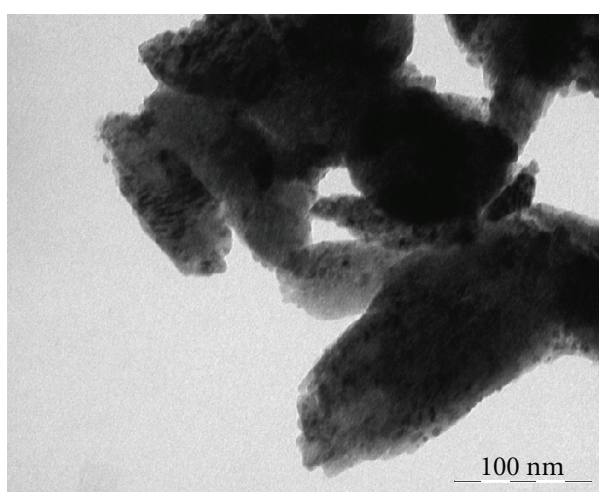

(a)

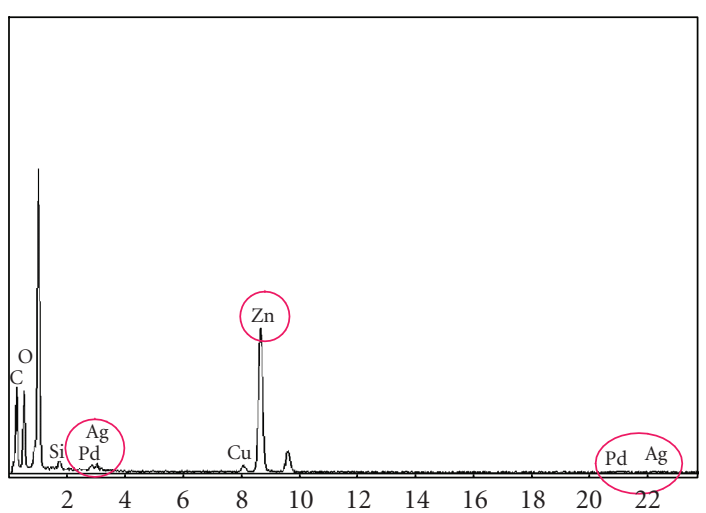

(b)

FIgURE 2: TEM images (a) and EDXS data (b) of the Pd-Ag/ZnO catalyst prepared by $\gamma$-irradiation.

TABle 2: Catalytic efficiency of Pd-M/ZnO catalysts in Suzuki reaction. Reaction conditions: Pd-M/ZnO catalysts (0.4 mmol), aryl halide (3 mmol), boronic acid $(6 \mathrm{mmol}), \mathrm{K}_{3} \mathrm{PO}_{4}(12 \mathrm{mmol})$, in EtOH $(50 \mathrm{~mL})$, at $78^{\circ} \mathrm{C}$, for 3 hours, yield obtained from HPLC data.

\begin{tabular}{|c|c|c|c|c|c|}
\hline Entry & Catalysts & Yield (\%) & Aryl halede & Boronic acid & Product \\
\hline 1 & $\mathrm{Pd} / \mathrm{C}$ & 99.5 & & & \\
\hline 2 & $\mathrm{Pd} / \mathrm{ZnO}$ & 99.0 & & & \\
\hline 3 & $\mathrm{Pd}-\mathrm{Ni} / \mathrm{ZnO}$ & 99.2 & & & \\
\hline 4 & $\mathrm{Pd}-\mathrm{Cu} / \mathrm{ZnO}$ & 99.1 & & $\mathrm{~B}(\mathrm{OH})_{2}$ & $\begin{array}{l}\text { GC-mass data; } 7.8 \mathrm{~min} \text {, } \\
\mathrm{MW}=154\end{array}$ \\
\hline 5 & $\mathrm{Pd}-\mathrm{Ag} / \mathrm{ZnO}$ & 100 & & & \\
\hline 6 & $\mathrm{Pd} / \mathrm{C}$ & 95.6 & & & \\
\hline 7 & $\mathrm{Pd} / \mathrm{ZnO}$ & 96.9 & & & \\
\hline 8 & $\mathrm{Pd}-\mathrm{Ni} / \mathrm{ZnO}$ & 97.1 & & & \\
\hline 9 & $\mathrm{Pd}-\mathrm{Cu} / \mathrm{ZnO}$ & 98.0 & & $\mathrm{~B}(\mathrm{OH})_{2}$ & GC-mass data; $8.3 \mathrm{~min}$, \\
\hline 10 & $\mathrm{Pd}-\mathrm{Ag} / \mathrm{ZnO}$ & 98.3 & & & $\mathrm{MW}=160$ \\
\hline 11 & $\mathrm{Pd} / \mathrm{C}$ & 37.0 & & & \\
\hline 12 & $\mathrm{Pd} / \mathrm{ZnO}$ & 38.0 & & & \\
\hline 13 & $\mathrm{Pd}-\mathrm{Ni} / \mathrm{ZnO}$ & 42.8 & 1 & & \\
\hline 14 & $\mathrm{Pd}-\mathrm{Cu} / \mathrm{ZnO}$ & 44.7 & & $\mathrm{~B}(\mathrm{OH})_{2}$ & GC-mass data; $16.4 \mathrm{~min}$, \\
\hline 15 & $\mathrm{Pd}-\mathrm{Ag} / \mathrm{ZnO}$ & 40.4 & & & $\mathrm{MW}=207$ \\
\hline
\end{tabular}




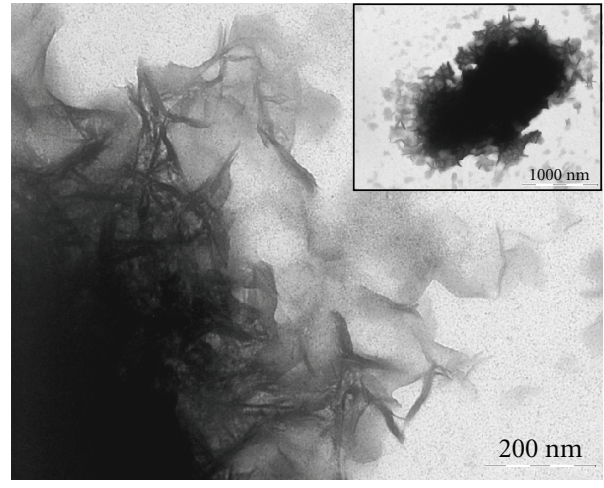

(a)

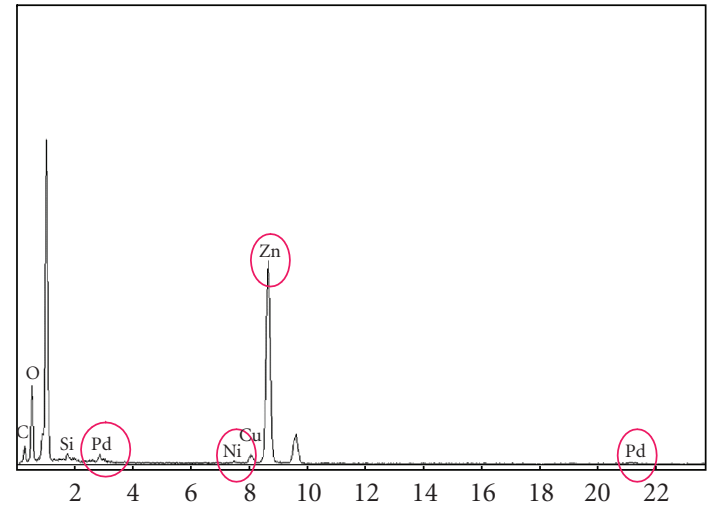

(b)

Figure 3: TEM images (a) and EDXS data (b) of the Pd-Ni/ZnO catalyst prepared by $\gamma$-irradiation.

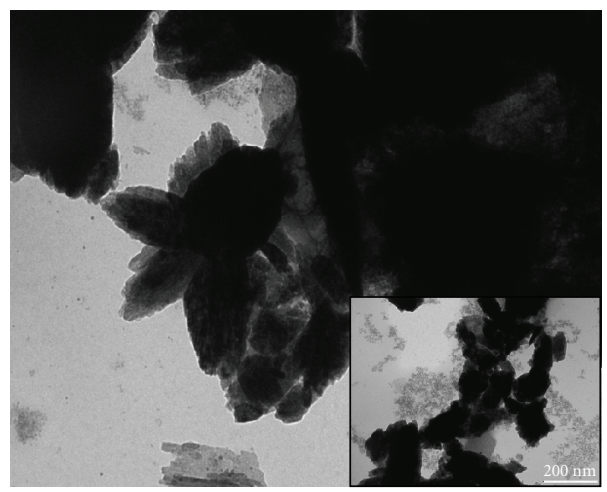

(a)

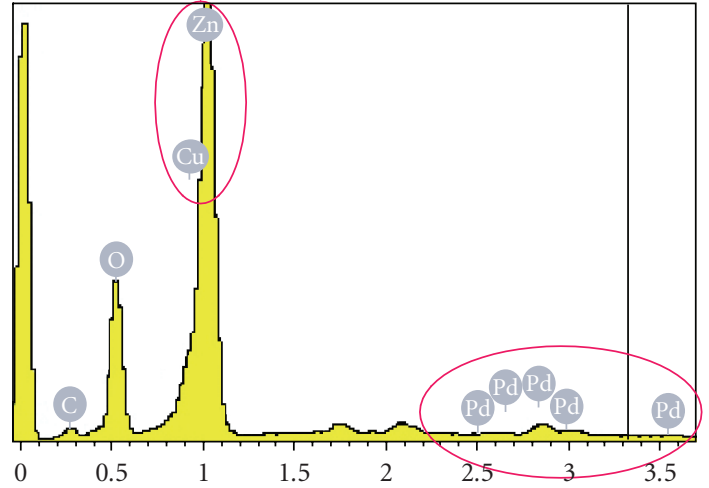

(b)

FIgURe 4: TEM images (a) and EDXS data (b) of the Pd-Cu/ZnO catalyst prepared by $\gamma$-irradiation.

$200 \mathrm{kV}$ using a Hitachi HF-2000 TEM equipped with a field emission source. An energy dispersive X-ray spectrometer (EDXS) attached to the Hitachi HF-2000 TEM was used to analyze the chemical composition of the samples. FETEM specimens were prepared by placing microdrops of colloid solution on a carbon film supported on copper grids. The elemental analysis of the catalysts was performed by an Ultima-C Inductively Coupled Plasma-Atomic Emission Spectrometer (ICP-AES, Jobin-Yvon Co. USA).

\section{Results and Discussion}

3.1. Characterization of $P d-M / Z n O$ Catalysts Prepared by $\gamma$ irradiation. Figure 1 shows the TEM image and the EDXS data of the $\mathrm{Pd} / \mathrm{ZnO}$ catalysts. The TEM image clearly shows the Pd particles are successfully loaded on the surface of the $\mathrm{ZnO}$ nanopowder. The presence of $\mathrm{Pd}$ is also seen in the TEM-EDXS spectrum. The formation of Pd nanoparticles from the metal ions can be explained by the following equation. In an aqueous solution, hydrated electrons were generated by $\gamma$-irradiation (see (1)):

$$
\mathrm{H}_{2} \mathrm{O} \longrightarrow \mathrm{e}_{\mathrm{aq}}{ }^{-}, \mathrm{H}_{3} \mathrm{O}^{+}, \mathrm{H}^{\cdot}, \mathrm{H}_{2}, \cdot \mathrm{OH}, \mathrm{H}_{2} \mathrm{O}_{2} \text {. }
$$

The Pd ions are reduced by the hydrated electrons to form metallic $\mathrm{Pd}\left(\mathrm{Pd}^{0}\right)$ (see (2)), which are aggregated to form more stable $\mathrm{Pd}$ particles $\left(\mathrm{Pd}_{\mathrm{agg}}\right)$ (see (3)):

$$
\begin{gathered}
\mathrm{e}_{\mathrm{aq}}{ }^{-}+\mathrm{Pd}^{2+} \longrightarrow \mathrm{Pd}^{0}, \\
n \mathrm{Pd}^{0} \longrightarrow \mathrm{Pd}^{2} \longrightarrow \mathrm{Pd}_{n} \longrightarrow \mathrm{Pd}_{\mathrm{agg}} .
\end{gathered}
$$

In (3), $n$ is the number of aggregated $\mathrm{Pd}^{0}$ and $\mathrm{Pd}_{\mathrm{agg}}$ is the aggregate in the final stable state.

Figure 2 shows a typical TEM image and the EDXS data of the Pd-Ag/ZnO catalysts. The TEM image and TEMEDXS data inform that the Pd-Ag alloy particles were formed on the surface of $\mathrm{ZnO}$ by $\gamma$-irradiation. In Figures 3 and 4 , the TEM and TEM-EDXS data were shown for Pd-Ni/ZnO and $\mathrm{Pd}-\mathrm{Cu} / \mathrm{ZnO}$ catalysts, respectively. It is seen in both figures that the Pd-M bimetallic nanoparticles are again successfully loaded on the surface of the $\mathrm{ZnO}$ nanopowder. It is noted that the loaded amount of the Pd-Ni/ZnO catalysts (shown in Figure 3) was smaller than that of the other particles. In order to determine the amounts of the metallic nanoparticles, an elemental analysis was performed on the nanoparticles using ICP-AES, and the results are shown in Table 1. The $\mathrm{Pd}$ content in $\mathrm{Pd}-\mathrm{Ni} / \mathrm{ZnO}(5.06 \%)$ is much lower than that in $\mathrm{Pd} / \mathrm{ZnO}$ (19.4\%), $\mathrm{Pd}-\mathrm{Ag} / \mathrm{ZnO}$ (9.73\%), and $\mathrm{Pd}-\mathrm{Cu} / \mathrm{ZnO}$ 


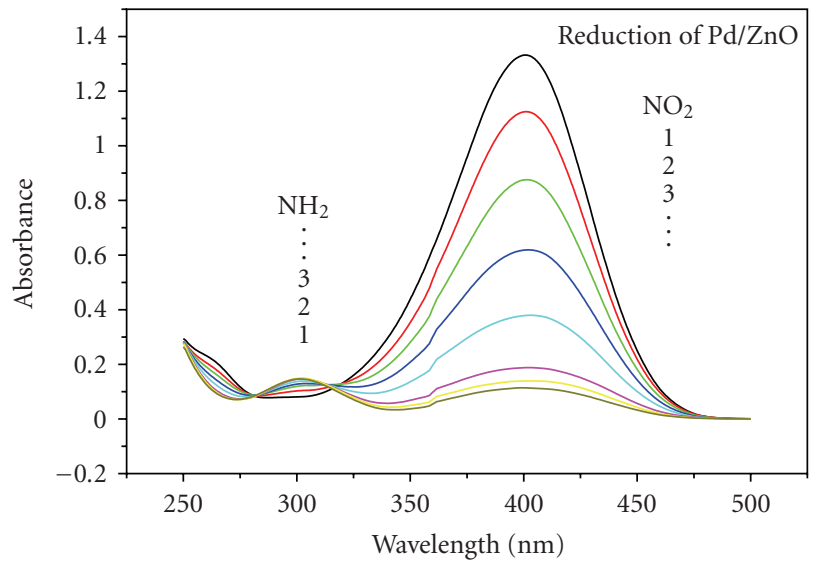

(a)

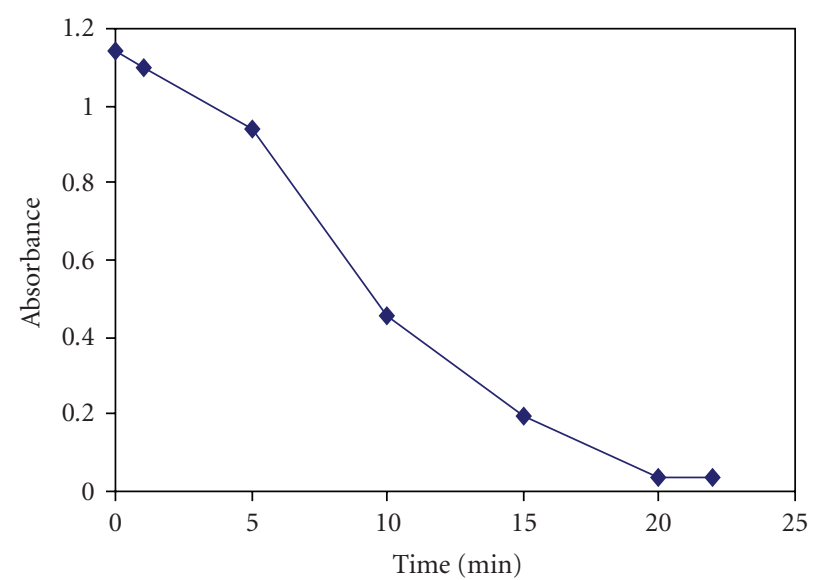

(b)

FIgURE 5: UV-Vis spectra (a) of the reduction of 4-NP and absorbance versus time plot (b) of the reduction of 4-nitrophenol by Pd/ZnO catalyst.

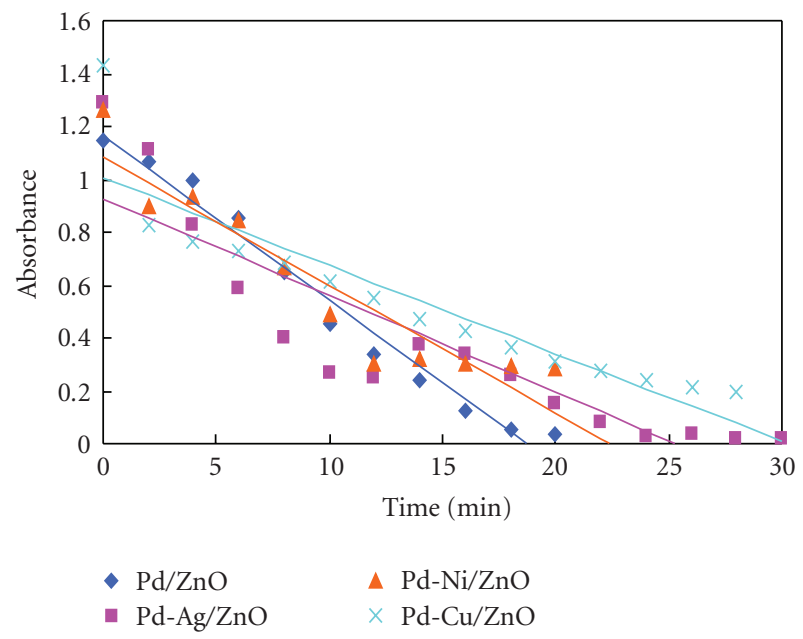

Figure 6: Absorbance versus time plot of reduction of 4nitrophenol by $\mathrm{Pd}-\mathrm{M} / \mathrm{ZnO}$ catalysts.

$(6.36 \%)$. Also, the $\mathrm{Ni}$ content in $\mathrm{Pd}-\mathrm{Ni} / \mathrm{ZnO}(0.65 \%)$ is much lower than the $\mathrm{Ag}$ content in $\mathrm{Pd}-\mathrm{Ag} / \mathrm{ZnO}(8.53 \%)$ and the $\mathrm{Cu}$ content in $\mathrm{Pd}-\mathrm{Cu} / \mathrm{ZnO}$ (11.3\%). The results shown in Table 1 confirm that a lesser amount of $\mathrm{Pd}-\mathrm{Ni} / \mathrm{ZnO}$ nanoparticles was formed than other nanoparticles. Belloni et al. [18-20] published that the control of the conditions for the synthesis of the metallic nanoparticle and alloy clusters. He concluded that the reduction of the respective metal ions should be related to the radiation dose, time, and concentration of metal ions.

3.2. Catalytic Efficiency of $\mathrm{Pd}-\mathrm{M} / \mathrm{ZnO}$ Catalysts. The $\mathrm{ZnO}-$ supported $\mathrm{Pd}$ and $\mathrm{Pd}-\mathrm{M}$ nanoparticles prepared in this study can be applied as a catalyst in hydrogenation. Figure 5 shows the UV-Vis spectra (a) and absorbance versus time plot (b) of the reduction of 4-nitrophenol by $\mathrm{Pd} / \mathrm{ZnO}$ catalysts. It has been observed that the intensity at $400 \mathrm{~nm}$ due to nitro group peak was decreased, while the intensity at $290 \mathrm{~nm}$ due to amine group peak was increased. This means the formation of 4-aminophenol. Pradhan et al. [21] published about the reduction of nitro group on 4nitrophenol by using sodium borohydride as a hydrogen source in the presence of the Pt-Ni nanoparticle as catalyst. Figure 6 exhibited that the absorbance versus time plot during reduction of 4-nitrophenol using $\mathrm{Pd}$ and $\mathrm{Pd}-\mathrm{M} / \mathrm{ZnO}$ $(\mathrm{M}=\mathrm{Ag}, \mathrm{Ni}$, and $\mathrm{Cu})$ catalysts. This data shows reduction process of 4-nitrophenol on $\mathrm{Pd}-\mathrm{M} / \mathrm{ZnO}$ monitored by UVVisible spectroscopy. The order of catalytic efficiency for $\mathrm{Pd}-\mathrm{M} / \mathrm{ZnO}$ catalysts was as follows: $\mathrm{Pd} / \mathrm{ZnO}>\mathrm{Pd}-\mathrm{Ni} / \mathrm{ZnO}$ $>\mathrm{Pd}-\mathrm{Cu} / \mathrm{ZnO}>\mathrm{Pd}-\mathrm{Ag} / \mathrm{ZnO}$. In a previous paper [22], we also prepared the PVP stabilized Pd colloids by $\gamma$-irradiation in aqueous solution without additional reducing agent. The Pd colloid was used as catalysts for the reduction of 2-, 3-, 4-nitrophenol, 2,4,6-trinitrotoluene, and 4-nitrobenzo-15crown in aqueous solution at room temperature. However, $\mathrm{Pd}$ colloid could not be recycled, while these $\mathrm{Pd}-\mathrm{M} / \mathrm{ZnO}$ catalysts could be recycled.

The ZnO-supported Pd and Pd-M nanoparticles prepared in this study can also be applied in Suzuki reactions as catalyst. Table 2 shows the catalytic efficiencies (measured by the reaction yield) of $\mathrm{Pd} / \mathrm{ZnO}$ and $\mathrm{Pd}-\mathrm{M} / \mathrm{ZnO}$ catalysts in three different Suzuki reactions. The reaction yield was determined by an HPLC with an ODS column, with $\mathrm{MeOH}$ as the mobile phase, and a UV/VIS detector set at $254 \mathrm{~nm}$. As shown in Table 2, in the first reaction, the catalytic efficiency (measured by the yield of product, 2-phenylthiophene) decreases in the order of $\mathrm{Pd}-\mathrm{Ag} / \mathrm{ZnO}>\mathrm{Pd}-\mathrm{Cu} / \mathrm{ZnO}>\mathrm{Pd}-$ $\mathrm{Ni} / \mathrm{ZnO}>\mathrm{Pd} / \mathrm{ZnO}$. However, $\mathrm{C}-\mathrm{C}$ coupling formation was not formed at no. 11-15 in Table 2, whereas the biboronic compound was mainly obtained. Figure 7 shows HPLC and GC/Mass data obtained for the reactants and the products of biphenyl compound in Suzuki reactions. There are two important factors, such as catalytic efficiency and recycling, in catalytic reaction. Figure 8 show the recycling results of $\mathrm{Pd}-\mathrm{Ag} / \mathrm{ZnO}$ catalysts in the Suzuki reaction. The product yield of 2-phenylthiophene was $98.9 \%$ in the first reaction. 


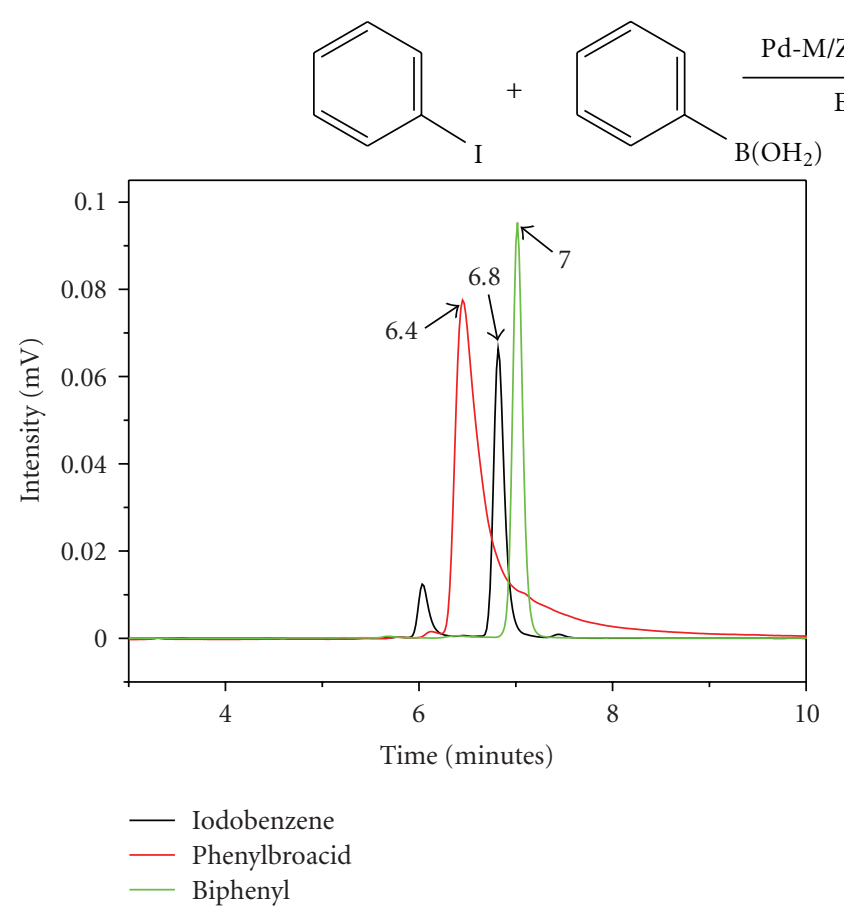

(a)
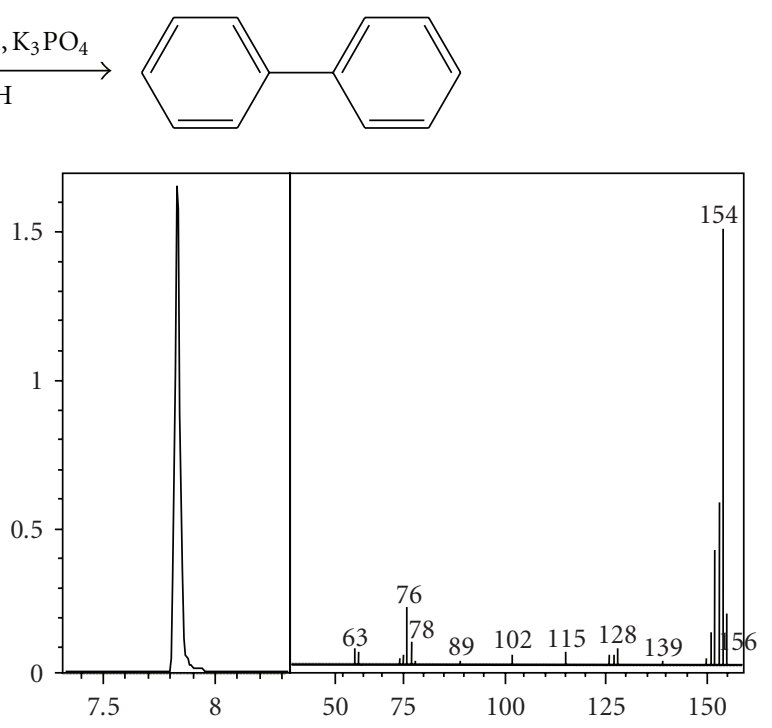

(b)

FIGURE 7: HPLC chromatograms of standard (a) and GC/Mass spectra (b) of biphenyl compound.

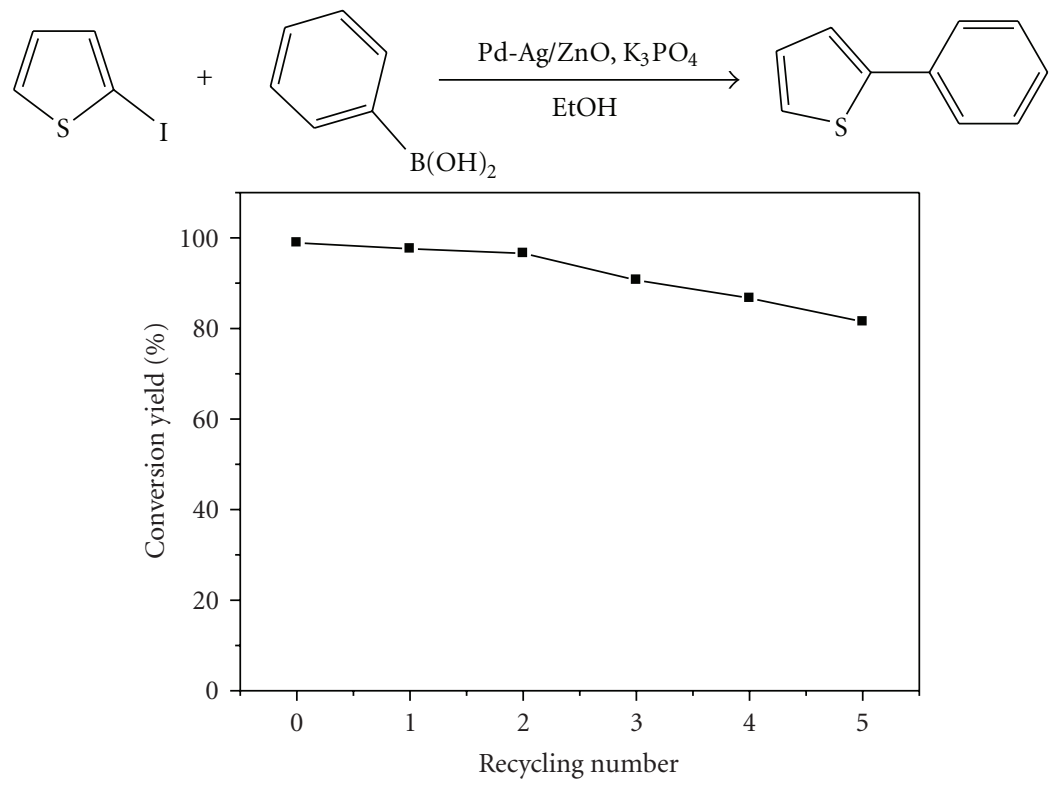

Figure 8: Recycling results of $\mathrm{Pd}-\mathrm{Ag} / \mathrm{ZnO}$ catalyst.

After the fifth recycling, the yield was $81.5 \%$. These results indicate that the $\mathrm{ZnO}$ supported $\mathrm{Pd}$ and $\mathrm{Pd}-\mathrm{M}$ nanoparticles prepared by $\gamma$-irradiation were good catalysts in the Suzuki reaction.

\section{Conclusion}

The $\mathrm{Pd} / \mathrm{ZnO}$ and $\mathrm{Pd}-\mathrm{M} / \mathrm{ZnO}$ catalysts $(\mathrm{M}=\mathrm{Ag}, \mathrm{Cu}$, and $\mathrm{Ni})$ were one-pot synthesized by $\gamma$-irradiation in an $\mathrm{MeOH}$ - water mixture without a reducing agent. TEM, TEM-EDXS, and ICP-AES data showed that the Pd and Pd-M $(M=A g$, $\mathrm{Cu}$, and $\mathrm{Ni}$ ) nanoparticles were successfully loaded on the surface of the $\mathrm{ZnO}$ nanopowder. The catalytic efficiencies of the $\mathrm{Pd}-\mathrm{M} / \mathrm{ZnO}$ catalysts were examined in hydrogenation and Suzuki reactions. In hydrogenation of 4-nitrophenol, the catalytic efficiency of $\mathrm{Pd}$ and $\mathrm{Pd}-\mathrm{M} / \mathrm{ZnO}$ catalysts was similar. In the Suzuki reactions, the catalytic efficiency (measured by the yield of the product) decreases in the order 
of $\mathrm{Pd}-\mathrm{Ag} / \mathrm{ZnO}>\mathrm{Pd}-\mathrm{Cu} / \mathrm{ZnO}>\mathrm{Pd}-\mathrm{Ni} / \mathrm{ZnO}>\mathrm{Pd} / \mathrm{ZnO}$. In comparison of the catalytic efficiency between $\mathrm{Pd}-\mathrm{M} / \mathrm{ZnO}$ and the commercial $\mathrm{Pd} / \mathrm{C}$ catalyst, the catalytic efficiency of $\mathrm{Pd}$ and $\mathrm{Pd}-\mathrm{M} / \mathrm{ZnO}$ catalysts prepared by $\gamma$-irradiation was higher than that of the commercial $\mathrm{Pd} / \mathrm{C}$. The heterogeneous $\mathrm{Pd}-\mathrm{M} / \mathrm{ZnO}$ catalysts prepared by $\gamma$-irradiation can be used for carbon-carbon coupling reactions such as Still-, Heck-, and Sonogashira-reactions.

\section{Acknowledgment}

This research was supported by the Nano R\&D Program (M10803001311-08M0300-31110) and the National Nuclear Technology Program (M20802000206-08B020020610) through the Korea Science and Engineering Foundation funded by the Ministry of Science \& Technology.

\section{References}

[1] M. Al-Hashimi, A. C. Sullivan, and J. R. H. Wilson, "Palladium ethylthioglycolate modified silica-a new heterogeneous catalyst for Suzuki and Heck cross-coupling reactions," Journal of Molecular Catalysis A, vol. 273, no. 1-2, pp. 298-302, 2007.

[2] H. Mahdavi, A. Zirakzadeh, and J. Amani, "Modified crosslinked polyacrylamide supported palladium salts as a new heterogeneous catalyst for Heck reaction," Reactive and Functional Polymers, vol. 67, no. 8, pp. 716-722, 2007.

[3] M. Cai, Q. Xu, and Y. Huang, "Heterogeneous Suzuki reaction catalyzed by MCM-41-supported sulfur palladium(0) complex," Journal of Molecular Catalysis A, vol. 271, no. 1-2, pp. 93-97, 2007.

[4] T. K. Sau and C. J. Murphy, "Room temperature, high-yield synthesis of multiple shapes of gold nanoparticles in aqueous solution," Journal of the American Chemical Society, vol. 126, no. 28, pp. 8648-8649, 2004.

[5] T. S. Ahmadi, Z. L. Wang, T. C. Green, A. Henglein, and M. A. El-Sayed, "Shape-controlled synthesis of colloidal platinum nanoparticles," Science, vol. 272, no. 5270, pp. 1924-1925, 1996.

[6] S.-D. Oh, M.-R. Kim, S.-H. Choi, et al., "Radiolytic synthesis of $\mathrm{Pd}-\mathrm{M}(\mathrm{M}=\mathrm{Ag}, \mathrm{Au}, \mathrm{Cu}, \mathrm{Ni}$ and $\mathrm{Pt})$ alloy nanoparticles and their use in reduction of 4-nitrophenol," Journal of Industrial and Engineering Chemistry, vol. 14, no. 5, pp. 687-692, 2008.

[7] S.-J. Kim, S.-D. Oh, S. Lee, and S.-H. Choi, "Radiolytic synthesis of $\mathrm{Pd}-\mathrm{M}(\mathrm{M}=\mathrm{Ag}, \mathrm{Ni}$, and $\mathrm{Cu}) / \mathrm{C}$ catalyst and their use in Suzuki-type and Heck-type reaction," Journal of Industrial and Engineering Chemistry, vol. 14, no. 4, pp. 449456, 2008.

[8] S.-H. Choi, "Hydrogenation of cis,cis-1,3-cyclooctadiene over MCM-41 embedded with $\mathrm{Pd}, \mathrm{Ag}$, and $\mathrm{Pd}_{50} / \mathrm{Ag}_{50}$ alloy nanoparticles," Journal of Industrial and Engineering Chemistry, vol. 10, no. 6, pp. 1015-1024, 2004.

[9] S.-D. Oh, K. R. Yoon, S.-H. Choi, et al., "Dispersion of Pt-Ru alloys onto various carbons using $\gamma$-irradiation ," Journal of Non-Crystalline Solids, vol. 352, no. 4, pp. 355-360, 2006.

[10] J. Ding, K.-Y. Chan, J. Ren, and F.-S. Xiao, "Platinum and platinum-ruthenium nanoparticles supported on ordered mesoporous carbon and their electrocatalytic performance for fuel cell reactions," Electrochimica Acta, vol. 50, no. 15, pp. 3131-3141, 2005.

[11] S. Rojas, F. J. García-García, S. Järas, M. V. Martínez-Huerta, J. L. G. Fierro, and M. Boutonnet, "Preparation of carbon supported Pt and PtRu nanoparticles from microemulsion: electrocatalysts for fuel cell applications," Applied Catalysis A, vol. 285, no. 1-2, pp. 24-35, 2005.

[12] N. Pradhan, A. Pal, and T. Pal, "Silver nanoparticle catalyzed reduction of aromatic nitro compounds," Colloids and Surfaces A, vol. 196, no. 2-3, pp. 247-257, 2002.

[13] A. H. Neilson, The Handbook of Environmental Chemistry, Volume 3: Anthropogenic Compounds, Part J: PAHs and Related Compounds: Biology, Lewis, Boca Raton, Fla, USA, 1997.

[14] C. E. Schwab, W. W. Huber, W. Parzefall, et al., "Search for compounds that inhibit the genotoxic and carcinogenic effects of heterocyclic aromatic amines," Critical Reviews in Toxicology, vol. 30, no. 1, pp. 1-69, 2000.

[15] S. Xu, X. Xi, J. Shi, and S. Cao, "A homogeneous catalyst made of poly(4-vinylpyridine-co- $N$-vinylpyrrolidone)-Pd(O) complex for hydrogenation of aromatic nitro compounds," Journal of Molecular Catalysis A, vol. 160, no. 2, pp. 287-292, 2000.

[16] R. S. Downing, P. J. Kunkeler, and H. van Bekkum, "Catalytic syntheses of aromatic amines," Catalysis Today, vol. 37, no. 2, pp. 121-136, 1997.

[17] R. M. Deshpande, A. N. Mahajan, M. M. Diwakar, P. S. Ozarde, and R. V. Chaudhari, "Chemoselective hydrogenation of substituted nitroaromatics using novel water-soluble iron complex catalysts," Journal of Organic Chemistry, vol. 69, no. 14, pp. 4835-4838, 2004.

[18] J. Belloni, "Nucleation, growth and properties of nanoclusters studied by radiation chemistry: application to catalysis," Catalysis Today, vol. 113, no. 3-4, pp. 141-156, 2006.

[19] J. L. Marignier, J. Belloni, M. O. Delcourt, and J. P. Chevalier, "Microaggregates of non-noble metals and bimetallic alloys prepared by radiation-induced reduction," Nature, vol. 317, no. 6035, pp. 344-345, 1985.

[20] J. L. Marignier and J. Belloni, "Nanoaggregates of nickel generated by radiolysis," Journal de Chimie Physique et de Physico-Chimie Biologique, vol. 85, p. 21, 1988.

[21] N. Pradhan, A. Pal, and T. Pal, "Silver nanoparticle catalyzed reduction of aromatic nitro compounds," Colloids and Surfaces A, vol. 196, no. 2-3, pp. 247-257, 2002.

[22] C.-G. Hwang, K. Sang-Ho, O. J. Hoon, M.-R. Kim, and S.H. Choi, "Reduction of aromatic nitro compounds on Pd colloids prepared by $\gamma$-irradiation," Journal of Industrial and Engineering Chemistry, vol. 14, no. 6, pp. 864-868, 2008. 

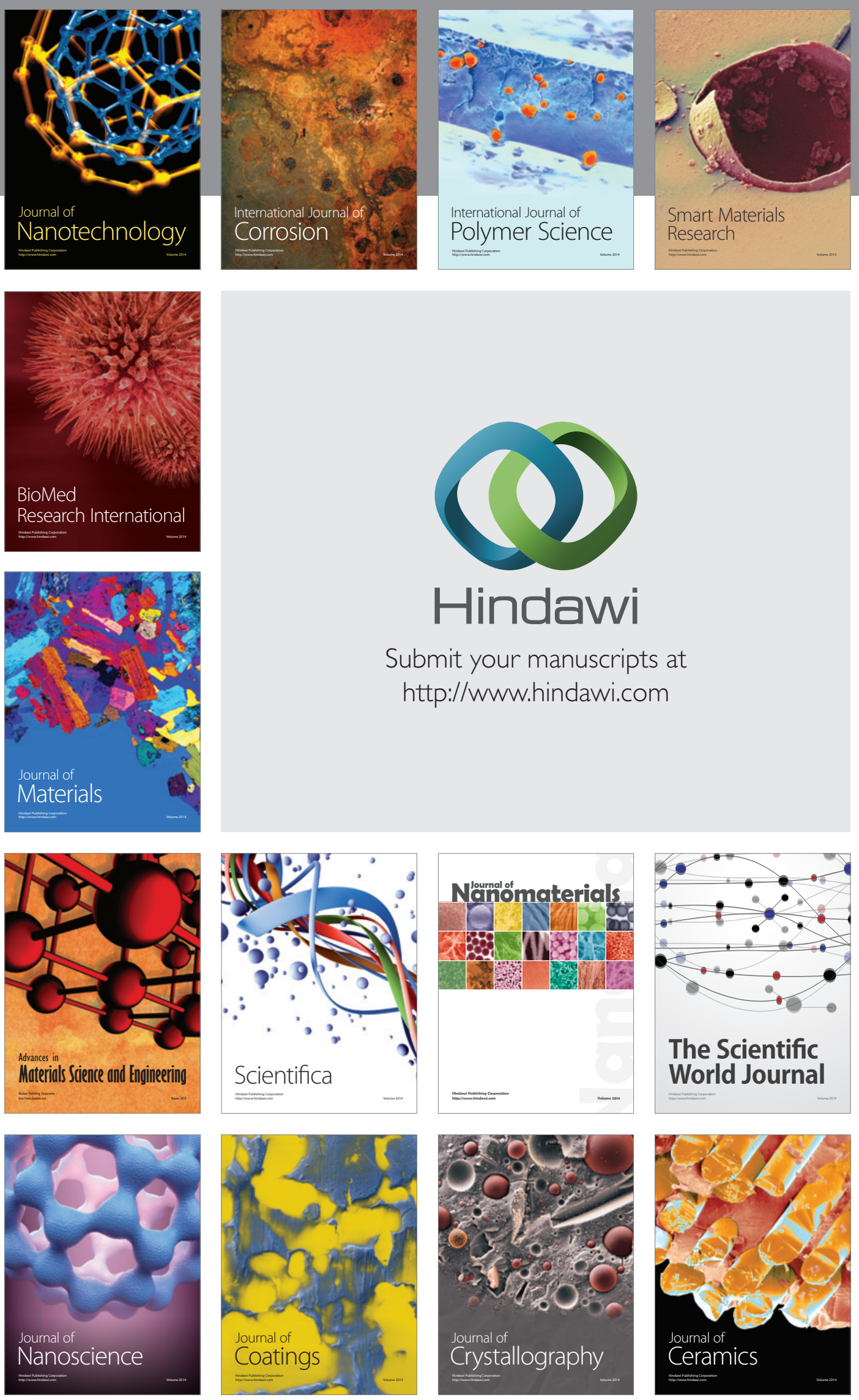

The Scientific World Journal

Submit your manuscripts at

http://www.hindawi.com

\section{World Journal}

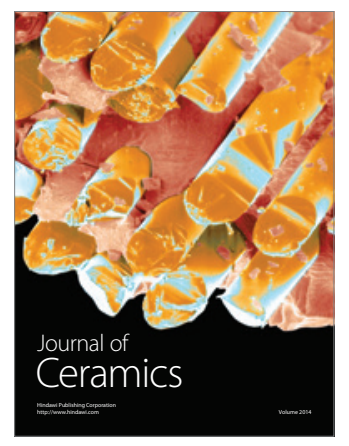

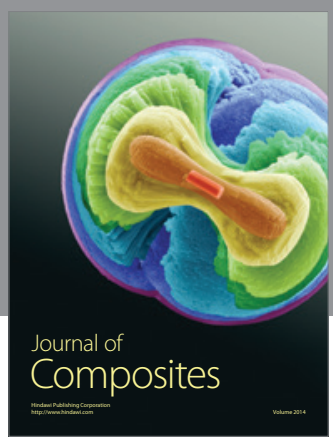
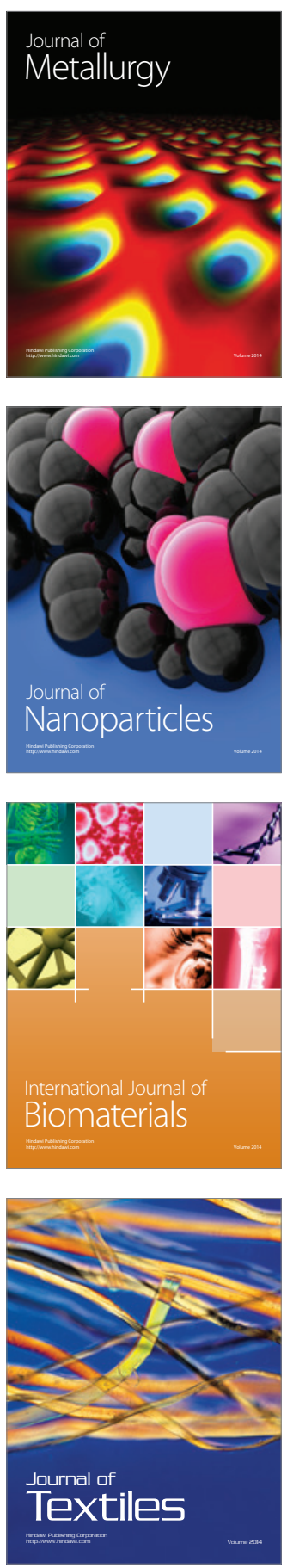